\title{
Analysis of Self-Esteem Levels of Students in Physical Education and Sports High School
}

\author{
Fahri Akçakoyun \\ Correspondence: Fahri Akçakoyun, School of Physical Education and Sports, Balikesir University, 10145, Balikesir, \\ Turkey.
}

Received: December 21, 2017

doi:10.11114/jets.v6i2.2951

\author{
Accepted: January 10, 2018 \\ Online Published: January 23, 2018
}

URL: https://doi.org/10.11114/jets.v6i2.2951

\begin{abstract}
The purpose of this study is to examine the self-esteem levels of the students at Balikesir University Physical Education and Sports High School according to the variables such; gender, age, body-mass index (BMI), education department, class, sporting situation and sport branch (individual sport-team sport). While the universe of the study has been formed by students in Balikesir physical education and sports high school, the sample group has been consisted of a total of 292 students; 108 of whom are female and 184 male, who have been randomly selected from these students. In this study Rosenberg self-esteem scale, developed by Rosenberg (1965) and adapted to Turkish language by Cuhadaroglu (1986) has been used. Kolmogorov- Smirnov normality test, Mann-Whitney U and Kruskal- Wallis test has been used in the analysis of the data obtained from study. Self Esteem Score (SES) is calculated for each individual. As a result of the study, it has been found that the self-esteem averages of the physical education and sports high school students are very close to each other in gender and sport branch factors, and no significant change has been seen $(p>0,05)$ however according to variable; whether they do sport or not; those who perpetually do sport have higher self-esteem than those who do not, and this change is statistically significant $(p<0.05)$ and according to age, class and body-mass index there is no significant difference ( $>0,05)$; and in the comparison among the departments; the average scores of the students of physical education and sports teaching department are higher than the average scores of the students of sports administration department, however this difference is not significant. It has been also understood that the average scores of the physical education and sports teaching students is higher than the students of coaching department and this change is statistically significant $(\mathrm{p}<0,05$.).
\end{abstract}

Keywords: self, self-esteem, physical education and sports students

\section{Introduction}

The self constitutes a very strong and independent part of the personality and the studies has done on it goes back to the Greeks, especially to Aristotle (Cevher ve Bulus, 2007). The self is the sum of the opinions of the individual on his/her personality and self-recognition and evaluation (Koknel, 1984). The self is an organized, consistent concept that is the result of the perception of the positive and negative aspects of self 's features and its interaction with other people (Gectan, 2000). Burns states that self is created as a result of the influence by those, who are important to the individual, and that there are three distinct selves. These;

1- Self-respect: It is the concept that an individual has about his or her abilities, status and role.

2- Social self : The evaluation of self according to the acceptance of others

3- Ideal self: It is the level of self that the individual aims to be. These three levels of self are four dimensional as; physical, social, academic and emotional (Altintas, 1989).

Self-esteem includes the individual`s general appraisal of himself/herself and his judgment about his/her worthiness (Karaaslan, 1993; Baser et al. 1998; Taysi, 2000; Izgic et al. 2001). Factors such as self-esteem, self-esteem, ability to demonstrate knowledge and skills and success, acceptance within the society, and acceptance of physical characteristics have an important place in the formation and development of self-esteem (Karaaslan, 1993; Yilmaz, 2000; Izgic et al. 2001). The concept of self-esteem was first handled by William James. According to James, the degree of self-esteem can be determined by the level of self-harmony and the rate of success or desire (Guney, 1982).

Self-esteem is the degree to which a person perceives a positive or negative attitude toward himself or how much an 
individual feel as self-sufficient, safe or important. Inadequate self-esteem is known to lead to have an extreme rigorous life philosophy, insidiousness, passive behaviors, psychosomatic diseases, and aggressive behaviors (Cuhadaroglu 1986).

In this study, the self-esteem levels of the athletes who are students of Balikesir University Physical Education and Sports High School has been examined according to gender, age, body-mass index, education department, class, sporting situation and sport scene variables.

\section{Material and Method}

A casual comparative research model has been used in this study. While the study universe has been formed by students in Balikesir physical education and sports high school, the sample group consisted of total of 292 students, 108 female and 184 male students that has been selected randomly.

\subsection{Data Collection}

A quartet likert scale type “Rosenberg self-esteem scale` developed by Rosenberg (1965) and adapted to Turkish language by Cuhadaroglu (1986) has been used in this study. Cuhadaroglu calculated the general validity of the scale as $71 \%$. In the reliability studies, self-esteem is $75 \%$, continuity of self-concept is $75 \%$, trust in people is $55 \%$, sensitivity of criticism is $48 \%$, depressive affect is $70 \%$, fancifulness is $75 \%$, psychomotor symptoms is $89 \%$, feelings of threats among people are $46 \%$,degree of participation in discussions $51 \%$ parental interest $51 \%$, relationship with father $79 \%$, psychic isolation $60 \%$ (Oner, 1997; Satilmis, 1988).

The height and weight declared by the students in the personal information form has been used for the calculation of the body mass index. The body weight has been obtained by proportioning the body length in meter to its square meter. Body weight $(\mathrm{kg}) /$ body length square has been used. Body mass index has been calculated using $\left(\mathrm{BMI}=\right.$ weight/lenght $\left.{ }^{2}\right)$ formula.

\subsection{Analysis of Data}

Kolmogorov-Smirnov normality test, Mann-Whitney U and Kruskal-Wallis test has been used in the analysis of data obtained from the study. Self-esteem value (BSP) for each individual has been calculated.

\section{Results}

Table 1. Self- respect values based on gender, sporting situation, sporting factors

\begin{tabular}{|c|c|c|c|c|c|}
\hline & & $\mathbf{N}$ & $\begin{array}{c}\text { SES }(\mathbf{m}) \\
\text { (Self Esteem Score) }\end{array}$ & $\begin{array}{c}\text { Test } \\
\text { Statistic }(Z) \\
\end{array}$ & $\mathbf{p}$ \\
\hline \multirow{2}{*}{ Gender } & Female & 108 & 32,75 & \multirow{2}{*}{0,428} & \multirow{2}{*}{0,669} \\
\hline & Male & 184 & 32,53 & & \\
\hline \multirow[b]{2}{*}{ Sporting situation } & Exercise regularly & 200 & 33,14 & \multirow[b]{2}{*}{$-2,911$} & \multirow[b]{2}{*}{$0,004^{* *}$} \\
\hline & $\begin{array}{l}\text { Exercise } \\
\text { non- regularly }\end{array}$ & 92 & 31,58 & & \\
\hline \multirow{2}{*}{ Sport Branch } & Individual & 161 & 32,63 & \multirow{2}{*}{0,197} & \multirow{2}{*}{0,844} \\
\hline & Team sports & 131 & 32,53 & & \\
\hline
\end{tabular}

As can be seen from table 1, the self-esteem averages of physical education and sports college students are gender (female: 32,75; male: 32,53) and sport branch (individual sports: 32, 63; team sports: 32, 53) (p>0.05), the self-esteem score averages of the students who constantly exercise according to sporting variable were not significantly different from the self-esteem average scores of the non-athletic students and this change was statistically significant $(\mathrm{p}<0.05)$.

Table 2. Self-esteem values based on age, education department, class, body-mass index factors

\begin{tabular}{|c|c|c|c|c|c|c|}
\hline & & $\mathbf{N}$ & $\begin{array}{l}\text { SES } \\
(\mathbf{m})\end{array}$ & $\begin{array}{c}\text { Test Statistic } \\
\left(\mathbf{X}^{2}\right)\end{array}$ & $\mathbf{p}$ & $\begin{array}{l}\text { Differences } \\
\text { Between Groups }\end{array}$ \\
\hline \multirow{4}{*}{ Age } & $17-19$ & 92 & 32,87 & \multirow{4}{*}{3,429} & \multirow{4}{*}{0,33} & \multirow[t]{4}{*}{ 200 } \\
\hline & $20-22$ & 142 & 32,36 & & & \\
\hline & $23-25$ & 43 & 32,26 & & & \\
\hline & 26 and over & 15 & 34,43 & & & \\
\hline \multirow{3}{*}{$\begin{array}{l}\text { Education } \\
\text { Department }\end{array}$} & Teaching & 77 & 33,29 & \multirow{3}{*}{6,320} & \multirow{3}{*}{$0,042^{*}$} & \multirow{3}{*}{$\begin{array}{l}1 \Leftrightarrow 2(\mathrm{p}=0,03) \\
2 \Leftrightarrow 3(\mathrm{p}=0,05)\end{array}$} \\
\hline & Coaching & 136 & 31,91 & & & \\
\hline & $\begin{array}{l}\text { Sports } \\
\text { Management }\end{array}$ & 79 & 33,15 & & & \\
\hline \multirow{4}{*}{ Grade } & 1 & 99 & 33,38 & \multirow{4}{*}{6,160} & \multirow{4}{*}{0,104} & \multirow{4}{*}{ - } \\
\hline & 2 & 30 & 32,37 & & & \\
\hline & 3 & 80 & 32,49 & & & \\
\hline & 4 & 83 & 31,89 & & & \\
\hline \multirow{4}{*}{$\begin{array}{l}\text { Body- Mass } \\
\text { Index }\end{array}$} & Slim & 24 & 32,39 & \multirow{4}{*}{4,018} & \multirow{4}{*}{0,259} & \multirow{4}{*}{ - } \\
\hline & Normal & 226 & 32,55 & & & \\
\hline & Fat & 34 & 32,52 & & & \\
\hline & Obese & 8 & 36,17 & & & \\
\hline
\end{tabular}


As Table 2 reveals, there is no significant difference in the age, class and body-mass index factors of the self-esteem scores of the physical education and sports college students ( $>0,05)$; self-esteem scores of the students in physical education and sports teaching department are higher than the average scores of the students in sports management, but there is no significant difference between them $(p>0,05)$. Self-esteem scores of the students in physical education and sports teaching department are higher than the average scores of the students in the coaching department and this change is statistically significant $(\mathrm{p}=0,03)$.

\section{Discussion and Conclusion}

A total of 292 athletes, 108 female and 184 male students, has participated in this study which examined the self-esteem levels of the students attending physical education and sports college in terms of various variables.

It has been detected that students who has participate in this study has showed no significant difference in the level of self-esteem in the gender dimension ( $p>0,05$; Table 1). Baybek and Yavuz (2005) have achieved such a result in their study of university students` self- respect; there are no significant differences between the sexes in this study. In Cengil's study (2009) among first-year students of theology faculty; it is seen that there is no significant difference between students`gender status and self-esteem. According to Abbasoglu and Oncu`s (2013) research results also indicate that; there is no meaningful difference between their self-esteem in terms of gender dimension among physical education teacher candidates. It is seen that similar results are obtained in the research titled 'comparing the physical self-perceptions of the physical education students, teachers and dancers' (Akyol and his friends., 2015). There is no significant difference between sexes in a study conducted between university students who do and do not do sports (Mollaogullari and Alptug, 2013). According to the results of the research conducted among the candidates participating in the special talent examination of physical education and sports, there is no significant difference in gender factor (Gorgut et al. 2014). When the results of the field studies are examined, it is seen that their results are in parallel to our findings (Masrabaci, 1994; Eser, 2005; Altunbas, 2006; Aktug, 2006; Ozmen, 2007; Polat, 2007). After our research and in the light of literature, it can be said that there is no meaningful effect of the sex on self-esteem.

It has been discovered that the self-esteem score averages of the students who constantly exercise according to the sporting variable are higher than the self-esteem average scores of the perpetual non-athletic students and this change was statistically significant $(\mathrm{p}<0.05$, Table 1$)$. Similar results have been obtained in a study in which hearing impaired national athletes and self-esteem levels of hearing impaired persons who do not do sports have been investigated. It has been revealed that the individuals who play sports have higher self-esteem scores than those who do not and they differ significantly (Karakoc, 2010). It has been determined that there is a significant difference according to the averages obtained from self-esteem scale of the students who have participated in the research and the level of self-respect of teacher candidates who are interested in the sports is higher (Erbas et al., 2015). Kamal, Blais, Kelly and Exratnt (1995) concluded that the level of self-esteem of the sportsmen is higher than the others. Another study on the field by Pehlivan (2010) is a researcher on teacher candidates; it has concluded that teacher candidates who actively participated in this research has higher self-perceptions than those who did not participate. As seen; there are many studies in the field that are parallel with our findings. From these results it can be concluded that the self-esteems of the sportsmen are high. Because sports have positive effects on self-esteem (Ersan, Dogan and Dogan, 2009).

In our study, it has been determined that self-esteem averages of the students of physical education and sport high school is very close to each other, but there is no significant difference in sport/branch (individual and team) factors ( $>0,05 ;$ Table 1). Acak and Kaya (2015) has stated that the hearing footballers and the hearing-impaired soccer players who participated in their research has moderate self-esteem (Acak and Kaya, 2015). It has been determined that there is no significant relationship between the self-esteem levels of the handball players but their self-esteem scores are high (Gacar and Yalcin; 2012).There is significant difference in the physical self-perception, in terms of "sports ability" sub-dimension among team athletes and combat athletes and dancers (Akyol et al., 2015). A statistically significant difference has been found between the social self-esteem and the academic self-esteem of the students who participated in the Branch sports (football, tennis, basketball) summer sports school (Korkmaz, 2007). In the research, it is understood that there is no significant difference in self-esteem, whether these athletes play basketball, handball or football sports (Certel and Bahadir, 2012). It has been determined that there is no significant difference in the self-esteem scores of male wrestlers in the star category (Gencer, 2008). Studies in the literature have different results; however, it is thought that doing team or individual sports has positive effects on the self-esteem of the individual and there are different outcomes.

According to another finding in our study, physical education and sports high school students' self-esteem scores do not show a significant change in the age factor ( $>0,05$; Table 2). There is no significant difference between the self-esteem levels according to age groups (Baybek and Yavuz 2005). In the study group there is no statistically significant difference between the mean scores of the self-esteem subscale of 22 years and younger and 23 years of age and over 
(Guler, 2017). In a study involving two separate groups of age groups 8-18, 18-65; it has been shown that in social classes, the self-design is a relationship that varies according to the age of the individual (Gurhan, 1986).There is no relationship between the self-design and social class in the 8-11 year-old group and there is a high level of relationship, between the ages of 12 and 18 at middle level and, above 18 years (Karakoc, 2010). In a study in which different age groups has been sampled, the relationship between depression and self-esteem in adolescents has been examined and a negative relationship between depression and self-esteem has been found in adolescents (Gur, 1996). In a study that Saygili (2015) have conducted; self-esteem increases as the age increases. 16-year-old students have been found to have a statistically significant and high self-esteem score contrast to the 17-year-old students (Guztepe, 2017). Sportsmen`s self-respect scores do not show a significant difference according to the ages of the athletes (Gencer, 2008). There is no significant difference in the self-esteem level of students of both the sports science faculty and the theology faculty when comparing the self-esteem level of the students according to age groups (Unver et al., 2014). Differences have been determined between self-esteem and risk-taking levels among participating individuals (Aktas and Erhan, 2015) As you can see, there are different findings among the researches in the literature. Different results; are thought to be resulted from different socio-cultural structure and the cultivation styles of sampling groups participating in the research.

While the self-esteem averages of the physical education and sport college students do not show any significant difference in class variable ( $>0.05$, Table 2 ); the average scores of the students in physical education and sports teaching department are higher than the average scores of the students in sport management but there is no significant difference between them $(\mathrm{p}<0,05)$. The average scores of the students in physical education and sports teaching department are higher than the average scores of the students in the coaching department and this change was statistically significant $(\mathrm{p}<0,05)$. According to the results of the research, the self-esteem of the physical education teacher candidates shows a meaningful difference according to the class variable. The self-esteem score of teacher candidates who are studying in the $4^{\text {th }}$ grade is higher than the self-esteem of the teacher candidates who are studying in the $1^{\text {st }}, 2^{\text {nd }}$ and $3^{\text {rd }}$ grades (Abbasoglu and Oncu, 2013). Comparing the level of self-esteem with the self-esteem, while there is a significant difference in students of sports science faculty, no difference has been found in the students of faculty theology (Unver et al., 2014). Altunbas (2006) and Karadag et al. (2008) in their researches; the differences in the self-esteem scores of the teacher candidates studying in different classes are found to be significant for the students who are in the fourth grade. Participants who participated in the study have been found to have a meaningful difference in the comparison made in terms of departmental change. According to this; the level of self-esteem of students in physical education and sport teaching and mathematics departments were found to be higher than those in PDR students in psychological services in education department. Besides, it is seen that teacher candidates who are studying in the department of physical education and sport have the highest average compared to the teacher candidates of the other branches in the research group (Erbas et al., 2015). In his study Cengil (2009) has expressed that among first-year students of theology faculty, 50\% of the students who participated in the study have high self-esteem, $46.3 \%$ have moderate and 3.7\% have low self-respect. It has been determined that Baybek and Yavuz (2005) evaluated university students according to their departments and has found that there is no significant relationship in self-esteem levels between schools but self-esteem levels are high in a few departments and physical education and sports high school students.. According to the results of the same study, the $4^{\text {th }}$ grade students have the highest, and the lowest self-esteem levels are in preparatory class students; it has been found that there is not a significant difference $(p>0,05)$ between the levels of self-esteem according to the classes. Self-esteem scores have been found to be higher in the $3^{\text {rd }}$ grade than in the $2^{\text {nd }}$ grade, and those who are more happy to study in the physical education and sport teaching departments have higher scores than those the unstable ones (Soyturk and his friends,2015). According to the results of our research, in evaluation of the departments that the average of the self-esteem points of the students of physical education are respectfully higher; is thought to be due to their high chance of finding an occupation after graduation and the fact that they participate social life earlier than the others.

It has been determined that the self-esteem averages of physical education and sport high school students do not show any significant difference in body-mass index factor ( $>0.05$, Table 2). There is a direct relationship between body perception and self-esteem (Henriques and Calhoun, 1999). In another research, before starting to studies general self-perceptions of both groups has been measured. At the beginning no difference between the two groups has been detected. When the tests are repeated after six months; there has been a significant increase in perceptions of people following a regular sport program for six months, especially for their bodies, in contrast to others (Block, 1999). It has been found that there is a linear and low statistically a significant positive correlation between life satisfaction scores and body satisfaction scores of the weight lifters; that is to say, the level of body perception has a statistically significant effect on the self-esteem (Karademir et al., 2013). Asci (2004) has expressed that physical self-perception is influenced by gender and physical activity level, while males have more positive physical self-perception than females, and also those who are physically active individuals have more positive self-perception than those who are not. The physical 
self-perceptions of dancers has been found different from physical education students and teachers, in addition to this the physical self-perception of the students are thought to increase with age and experience (Akyol et al., 2015). In our study, according to body-mass index categories; 23 slim, 226 normal, 33 fat and 6 obese students has been found. As the sample of our study is made up of physical education and sport high school students, the number of 6 students in the obese category is quite significant and a rather high figure for us. Because individuals with a positive body image who find themselves physically fit are expected to develop positive self-concepts (Bastug, 2008).

Consequently; it has been understood that the self-esteem averages of physical education and sports high school students are very close to each other according to gender and sport branch factors, and there is no significant difference $(p>0,05)$ however according to the exercise variable; the self-esteem score averages of the students who do consistently exercise are found to have higher self-esteem scores, than those who do not and this change was statistically significant $(p<0,05)$; and in terms of age, class and body-mass index variables there is no significant difference $(p>0,05)$; in the evaluation that has been made according to education departments of the students; it has been found that the score averages of the students in the physical education and sports teaching department are higher than that of physical education and sports management, but there is no significant difference ( $p>0,05)$; however, the students in the physical education and sports teaching department have higher score average than those in coaching department and this change is statistically significant $(\mathrm{p}<0,05)$.

During the literature review, the fact that the self-esteem levels of the individuals doing sports are high has been frequently encountered. Taking this into consideration it is clear that encouraging to do sports constantly will be beneficial for societies and will add plus value to future generations. Finally, future researches, which compare the self-esteem levels of the individuals of different cultures will contribute to the development of science incontrovertibly. More studies on this subject should be made soon.

\section{References}

Abbasoglu, E., \& Oncu, E. (2013). Self-esteem of Physical Education Teacher Candidates and Their Attitudes Towards Teaching Profession. Journal of Ahi Evran University Kirsehir Education Faculty, 14(2), 407-425.

Acak, M., \& Kaya, O. (2015). Examination of Self-esteem and Aggression Levels of Hearing-Impaired and Non-hearing-Impaired Players. Inonu University, Journal of Physical Education and Sport Sciences, 2(2), 1-11.

Aktas, I., \& Erhan, S. (2015). Investigation of self-esteem and risk-taking level of individuals doing sport or not (the example of Erzurum province). Sportive Sight: Journal of Sports and Education, 2(2), 40-51.

Aktug, T. (2006). Examination of Peer Pressure and Self-esteem in Adolescents. Unpublished Master Thesis, Mersin University, Social Sciences Institute, Mersin, 55.

Akyol, P., Erim, V., \& Yamak, B. (2015). Comparison of self-perceptions of physical education students, teachers and the dancers. Journal of Sports and Performance Researches, 6(2).

Altıntas, E. (1989). Some factors that affect the coherence level between self and vocational-self of teacher training faculty. Unpublished Doktoral Thesis, Hacettepe University, Institute of Social Sciences, Ankara, 18.

Altunbas, C. (2006). Examination of the relationship between self-esteem levels and academic achievement of Physical Education and Sports High School. Unpublished Master Thesis, Cumhuriyet Universitesi, Institute of Health Sciences, Sivas, 29.

Altunbas, C. (2006). Examination of the relationship between self-esteem levels and academic achievement of Physical Education and Sports High School. Unpublished Master Thesis, Cumhuriyet Universitesi, Institute of Health Sciences, Sivas.

Asci, F. H. (2004). Comparison of physical self-perception according to gender and physical activity level. Journal of Sport Sciences Hacettepe 1. Of Sport Sciences, J5(1), 39-48.

Baser, M., Bayat, M., \& Tasci, S. (1998). Determining the self-esteem of students. Quality in Nursing and Midwifery Education and Practice Symposium Book, 145-151.

Bastug, G. (2008). A study on gender roles and body perception levels of female athletes. Unpublished Doctoral Thesis, Gazi University, Institute of Education Sciences, Department of Physical Education and Sports Teaching, Ankara.

Baybek, H., \& Yavuz, S. (2005). Examination of the self-esteem of Mugla Universitesi students. Mugla University Journal of Social Sciences Institute, 14, 73-95.

Block, M. E. (1999). Did We Jump on the Wrong Band wagon? Problems with Inclusion in Physical Education. Academic Research Library, U.S.A. 15(3), 30-37.

Cengil, M. (2009). Examination of the self-esteem levels of the Hitit University, Theology Faculty, 1. year students, 
according to different variables. Hitit University Journal of Theology Faculty, 8(15)5, 77-102.

Certel, Z., \& Bahadir, Z. (2012). Examination of the relationship of self-esteem, trait anger, anger expression styles in team sports athletes. Selcuk University Journal of Physical Education and Sport Sciences, 14(2), 157-164.

Cevher, F. N., \& Bulus, M. (2007). Self-concept and Self-esteem: Importance and Development. Journal of Academic Design, 2, 52.

Cuhadaroglu, F. (1996).The characteristics of psychological development in adolescence. Journal of Katki Pediatrics, 17(5), 273-288.

Erbas, M., Unlu, H., \& Davarci, T. (2015). Examination of self-esteem levels of physical education teacher candidates in terms different variables. Gazi University Journal of Gazi Education Faculty, 35(2), 267-281.

Ersan, E. E., Dogan, O., \& Dogan, S. (2009).The relationship between some socio-demographic characteristics and self-esteem levels in the students of Physical Education and Coaching Department. Clinic Psychiatry, 12, 35-42.

Eser, H. (2005). The relationship between religious belief and self-esteem among university students, Unpublished Master Thesis, Uludag University, Institute of Social Sciences, Bursa, 53.

Gacar, A., \& Yanlic, N. (2012). Examination of the self-esteem levels of 13-17- year-old adolescent handball players in terms of some variables. Journal of Sports and Performance Researches, 3(2), 45-50.

Gectan, E. (2000).Psychodynamic Psychiatry and Abnormal Behaviours, Remzi Kitabevi Publishing, Istanbul, 234.

Gencer, E. (2008). Relatioship between focus of control, self-esteem and success in male wrestlers of Yildiz category (Ege Bolgesi Yildizlar League Example).Master Thesis, Pamukkale University, Institute of Health Sciences, Denizli.

Gorgut, I., Eski, T., \& Gullu, M. (2014). Investigation of self presentations of the candidates who entered special talent examination of Physical Education and Sports High School. Kastamonu Journal of Education, 22(2), 743-760.

Guler, H. (2017). The relationship between self-esteem and family attitudes in university students. Master Thesis, Uskudar University, Institute of Social Sciences, Department of Applied Psychology, Istanbul.

Guney, S. (1982). Behavioral Sciences, 4th Edition, Nobel Publishing, Ankara 2008, s.214; F. J. Bruno, Introduction to History of Psychology, trans.: Nesrin Hisli, Ege University, Letter Faculty, Publication, Izmir, p. 72.

Gur, A. (1996). The relationship between self-esteem and depression in adolescents. Master Thesis, Hacettepe University, Institute of Social Sciences, Ankara.

Gurhan, C. (1986).Some factors that affect self design of high school students. Doctoral Thesis, Hacettepe University, Institute of Social Sciences, Ankara.

Guztepe S. Y. (2017). Investigation of the extrovert and introvert personalities and self-esteem of adolescents who do sport and do not. Unpublished Master Thesis, Beykent University, Institute of Social Sciences, Department of Psychology, Clinic Psychology Field. Istanbul.

Henriques, G. R., \& Calhoun, L.G. (1999). Gender and ethnic differences in the relationship between body esteem and self-esteem. J Psychology, Jul; 133:357-68.

Izgic, F., Akyuz, G., \& Dogan, O. Et al. (2001). Investigation of the relationship between social anxiety and body image with self-esteem in university students. 3P Journal, 9(4), 591-598.

Kamal, A.F.,Blais, C., Kelly, P., \& Exratnt, K. (1995). Self- esteem attribution components of athletes versus non-athletes. International Journal of Sport Psychology, 26(2), 189-195.

Karaaslan, A. (1993).Examination of self-esteem levels of student nurses and factors that affect it. Ege University H.Y.O. journal, 9(2), 21-29.

Karadag, G., Guner, I., Cuhadar, D., \& Ucan, O. (2008). Gaziantep University health school nursing students ' self-esteem. Journal of Firat Health Services, 3(7), 29-42.

Karademir, T., Turkcapar, U., Ulucan, H., \& Bahadir, Z. (2013). The relationship of Self-esteem and life satisfaction and body perception in weightlifters . Ahi Evran University Journal of Kirsehir Education Faculty (KEFAD), 14(3), 285-294.

Karakoc, O. (2010). Investigation of self-esteem levels of hearing impaired national athletes and hearing impaired people who do not do sports.. Master Thesis, Firat University, Institute of Health Sciences, Elazig.

Koknel, O. (1984). Personality, Altin Kitaplar Publishing, Istanbul, 77. 
Korkmaz, N. H. (2007). Relationship between summer sport schools and children's self-esteem. Uludag University Journal of Education Faculty, XX(1), 49-65.

Masrabaci, T. (1994). Examination of the self-esteem levels of Hacettepe University first-year students according to some variables. Unpublished Doctoral Thesis, Ankara University, Institute of Social Sciences, Ankara, 126.

Mollaogullari, H., \& Alptug, E. C. (2013). Examination of the self-esteem and assertiveness levels of university students that do sport or do not. Mugla Sitki Kocman University Journal of Social Sciences Institute, 31, 135-143.

Oner, N. (1997). Psychological Tests Used In Turkey, 3. Edition. Istanbul, Bogazici University Press, 458.

Ozmen, F. (2007). The effect of perceived family communication styles on the self-esteem of adolescents; An example of practice. Unpublished Master Thesis, Anadolu University, Institute of Social Sciences, Eskisehir, 75.

Pehlivan, Z. (2010). Analysis of physical self-perceptions and attitudes towards teaching profession of physical education teacher candidates. Education and Science, 35(156), 126-141.

Polat, A. (2007). Determination self-esteem levels and body image of Hemodialysis Patients in the province of Duzce. Unpublished Master Thesis, Abant Izzet Baysal University, Institute of Health Sciences, Duzce, 43.

Rosenberg, M. (1965). Society and the Adolescent Self Image, Princeton, Princeton University Press. https://doi.org/10.1515/9781400876136

Satilmis, G. (1988). Self-esteem of the Adolescents who live in Orphanage. Master Thesis, Anadolu Universitesi , Institute of Health Sciences, Department of Psychiatry, Eskisehir.

Saygili, G., Kesercioglu, T. I., \& Kirtas, H. (2015). Examination of the Impact of the Education level on Self-esteem. Journal of research in education and teaching, 4(2), 210-214.

Soyturk, M., Ozturk, O.T., Topuz, E., \& Yetim, H. (2015). Examination of the relationship between self-esteem and attitudes towards cheating in physical education teacher candidates (CBU, BESYO example). International Journal of Sport, Exercise and Training Sciences, 1(1), 20-30.

Taysi, E. (2000). Self-esteem, social support provided from friends and family. Master Thesis, Ankara University, Institute of Social Sciences, Department of Psychology, Ankara.

Unver, S., Cavusoglu, G., \& Islamoglu, I. (2014). Comparison of self-esteem and psychosomatic symptoms of Sport Sciences Faculty and Theologhy Faculty Students. International Journal of Science Culture and Sport August, Special Issue 2, 261-270. https://doi.org/10.14486/IJSCS198

Yilmaz, S. (2000). The relationship between the level of assertiveness and self-esteem of the school of nursing students. Master Thesis, Ataturk University, Institute of Health Sciences, Department of Psychiatry Nursing, Erzurum.

\section{Copyrights}

Copyright for this article is retained by the author(s), with first publication rights granted to the journal.

This is an open-access article distributed under the terms and conditions of the Creative Commons Attribution license which permits unrestricted use, distribution, and reproduction in any medium, provided the original work is properly cited. 